\title{
Küreselleşme ve Eriyen Kolektif Aidiyetler
}

Globalization and Melting Collective Identifications

\section{Dr. Öğr. Üyesi Muhittin Imı1}

Başvuru Tarihi: 02.07.2019

Kabul Tarihi: 03.12.2019

\section{Öz}

Kimilerine göre kökleri çok daha kadim zamanlara götürülebilen küreselleşme, açgözlü endüstriyel toplumun literatüre kazandırdı̆̆ bir kavram olarak 3’üncü dünya ülkelerinde her geçen gün daha fazla etki ve ă̆ırlı̆̆ını hissettirmektedir. Dilleri, dinleri, kültürleri, yüzleri, mimikleri, renkleri ve kimlikleri yutarak, öğüttü̈̆̈̈ her şeyi biçim, form ve tanımlarından arındıran küresel değirmen, dokunduğu her varlık ve bilgi türünü tektipleştirme konusunda son derece ustaca hareket etmektedir. Onun karşısında en güçlü kolektif hafizalar bile silinmekte, en kadim kültürlerin binlerce yıllık birikimi bir kalemde tozlaştırılarak, her gün yeniden üretilen postmodern ve tek kullanımlık değerler, günübirlik yaşanmak suretiyle her yeni güne yeniden başlayan öncesiz ve sonra kaygısı taşımayan geniş kitleler peydahlanmaktadır. Söz konusu kitleler, yaygın kitle iletişimi sayesinde kolay manipüle edilebilen, farkına varmadıklarından şikâyet etmedikleri ekonomik ve sosyal sömürü süreçlerine teşne, bir taraftan kimliksizliğin bütün özelliklerini barındırırken diğer yandan mikro kimliklerin savaş̧̧ları olma konusunda son derece hevesli topluluklar olarak her geçen gün çoğalmaya devam ediyorlar. Bu rüzgârın karşısında direnmeye çalışan milli ve dini kimlikler ise ne yapılması gerektiğine tam olarak karar veremediklerinden olsa gerek, düzensiz savunma hatlarlyla cılız direnişler göstermeye çabalıyorlar. Bilginin ve paranın sınır aşan yayılımı, özellikle ulusları ve dinleri birbirine benzeterek renksizleştirirken, direnen milli kimlikler ve özelde İslam dini, aynı zamanda alt kimliklerini/gruplarını canlandırmak suretiyle çıkarılan bel altı saldırılarla içeriden kuşatılmaktadır.

Bu kör döğüşü ve süreğen saldırı karşısında ulus-devlet yapısı ve İslam din dairesine düşen öncelikli görev, tüm bileşenlerini postmodern bir zeminde yeniden değerlendirmek suretiyle doğru tanımlanan bir hasma uygun araçlarla karşılık vermekten ibarettir.

Anahtar Kelimeler: Küreselleşme, Postmodernizm, Din, Kimlik, Ulus-Devlet

\footnotetext{
${ }_{1}^{1}$ Milli Savunma Üniversitesi Kara Harp Okulu Dekanlı̆̆ı Sosyoloji Bölümü, malazgirt2130@gmail.com, ORCID ID: 0000-0001-5124-7984
} 


\begin{abstract}
According to some, globalization, whose roots can be traced back to ancient times, is becoming more and more felt in the $3 r d$ world countries as a concept brought by greedy industrial society to the literature. By absorbing languages, religions, cultures, faces, facial expressions, colors and identities, the global mill cleans everything that it grinds from shapes, forms and definitions, and acts very skillfully in standardizing every type of being and knowledge it touches. Even the most powerful collective memories are erased, thousands of years of accumulation of the most ancient cultures are written off, postmodern and disposable values that are reproduced every day, and before and after the beginning of each new day, large masses that do not have any concern have been revealed. These masses continue to multiply day by day as highly enthusiastic communities about being the fighters of micro-identities on the one hand while being subjected to economic and social exploitation processes which are easily manipulated by widespread mass communication and which do not complain that they are not aware of. The national and religious identities that try to resist under this circumstances may not be able to decide exactly what to do, but they try to show weak resistance with irregular lines of defense. While the transboundary spread of knowledge and money discolors especially nations and religions, resisting national identities and Islamic religion in particular have been besieged by under-attack attacks to revive subidentities/groups, at the same time.

Against the ongoing attack and at cross purposes, the nation-state structure and the primary duty of the Islamic religious department is to respond to a correctly defined hostile by means of reevaluating all its components on a postmodern basis.
\end{abstract}

Keywords: Globalization, Postmodernism, Religion, Identity, Nation-state.

\title{
Giriş
}

Küreselleşme ismini verdiğimiz büyük ve tahripkâr çı̆̆, her ne kadar bugünün dünyasında yeni sayılabilecek bir tanımlamaya sahip ise de insanlığın kadim kolektif hafızasında çok derinlerde bir yerlerde atılmış bir kartopunun büyüyerek dönüşmüş halidir. Bununla birlikte, her geçen gün artan bir hızla önüne kattığı insanlığı tam anlamıyla tek tipleştirerek yutmaya ve bütün renkleri yok ederek beyaza boyamaya devam etmektedir. Büyük kolektif aidiyetler olarak insanlığa ana renkler sunan kurumsal dinler ve milli yapılar ise söz konusu çı̆̆ dalgasının yöneldiği temel hedefler olarak önlenemez ve öngörülemez olduğu düşünülen sonuçlarıyla yüzleşmeye devam etmektedirler.

Çalışma, başta bilgi olmak üzere insanlığın tüm üretimini sınır tanımaz biçimde görünür, bilinir ve paylaşılır hale getiren küreselleşmenin dini ve milli kimlikler üzerindeki etkilerini incelemeyi amaçlamaktadır. Bu kapsamda hafızasıyla birlikte küreselleşme olgusu, kurumsal dinler ve milletlerin maruz kaldıkları tehdidin boyutları, karmaşanın ortaya çıkardığı kültürel temasların olası sonuçları, törpüleyici unsurlar olarak dini kimlikler için postmodern sırf dini gruplar ve 
milli kimlikler için alt kimliklerin ortaya çıkışı nitel araştırma yöntemlerinden doküman inceleme metoduyla irdelenecektir.

\section{Küreselleşmenin Üretimi: Küçülen Dünya-Çatlayan Kimlikler}

Küreselleşme olgusu Baudrillard'ın (2018) deyimiyle her şeyin simülakrlardan oluştuğu bir simülasyon evreninden başka bir şey sunmaz insanlığa. Aslında gerçek olduğunu düşündüğ̈̈müz her şey gerçekmiş gibi tüketimimize sunulmuş kurgulardan ibarettir. $\mathrm{Bu}$ dünyada gerçeğe ne yer ne de tahammül yoktur. Gerçek ölmüştür.

Küreselleşme, 2'nci Dünya Savaşı'nın bitişi sonrasında başlayarak Sovyetler Birliği'nin yeni bir yapılanmaya gitme niyeti ile şekillenen sürecin -Sosyalist Bloğun dünya siyasetine yön verme konusunda Kapitalist Blok tarafından saf dışı bırakıldığ 1989 yılına kadar süren ve adına Soğuk Savaş denilen dönem- sonrasında dünyanın aldığı yeni yönelişi niteleyen bir kavram olarak yaygınlaşmıştır (Akca, 2012, s. 11). Küreselleşme, temelde avuç içine sığacak kadar küçülerek kolayca kontrol edilebilen, bu kontrolü sağlayan mekanizmalar açısından ise kör nokta barındırmayan bir dünya tasavvurunun dile dökülmüş halidir. Hâlihazırdaki şekliyle küreselleşmenin yapıp edimleri, yeryüzü küçük bir küre olarak tasavvur edildiğinde en dıştan her şeyi benzeştirir/birleştirirken en temelde dip kültür unsurlarını belirginleştirip ayrıştırarak öne çıkarmaya çalışmaktadır. Tek noktadan tetiklenen bu çift yönlü taarruz, öncelikle birer ara form olan güçlü ve geniş kolektif aidiyetleri -her halükarda milli ve dini kimlikleri- eritecek, peşi sıra daha büyük olanın dip kültürleri yutmasıyla amacına ulaşacaktır. Her ne kadar kavram olarak endüstri sonrası ve cilalı bir görüntü arz etse de kazındığında altından çok daha kadim bir geçmişin çıktığı görülecektir. Bu düşünce o kadar eskidir ki insanoğlu algıladığı dünya ne kadarsa o kadarına hâkimiyet için sürekli çabalamış, bunun için ittifaklar oluşturmuş, belirlenen temel ötekilerle savaşmaktan geri durmamıştır. Üstelik sadece siyasal-hegemonik bir talep değildir dünyayı çevrelemek isteyen. Aynı zamanda evrensel/yayılmacı dinler de bütün kâinat sadece kendi kıblesine dönsün isteyerek dini-hegemonik bir taleple sürekli büyümeye çalışmışlardır. Endüstri sonrasının küreselleşme kavramında öncüllerinden farklı olan en önemli şey temel aktördür. Kadim zamanlarda siyasetin kılıçla, diyanetin inançla yapmaya çalıştığı şeyi, endüstri toplumunda ticaret sermaye ve akültürasyon ile yapmaya çalışmaktadır. Üstelik dünya, önce keşifler sonra da kitle iletişimi sayesinde neredeyse avuç içine sığacak kadar küçülmüştür. Bu küçülmüş dünyada sermayenin serbest dolaşımının önündeki en büyük engeller ulus devlet yapıları ve küresel kültür aktarımının ise evrensel dinlerdir. Ulus devletler ve ulusal kimlikler; ulus altı aidiyetler ve mikro milliyetçi hareketlerin körüklenmesi sayesinde, evrensel dinler ise Ortodoks yapıya itirazlarla ayrılan sırf dini gruplar, işlevsizleştirme, söylemlerinin içeriğini boşaltma gibi yollarla örselenmeye çalışılır. Her iki durum için de ortaya çıkarılan kimlik savaşçıları, işaret edilen ötekilere -ulus devlet ve ana akım din- kıyasıya saldırır. Temel amaç, her iki kolektif aidiyetin -milli ve dini kimlikler- de anlam yitimine uğrayarak içinin boşaltılmasıdır. Bu sayede sermayenin sınır tanımayan bir geçiş üstünlüğü olacak, pazara sunulan her meta tek tipleşen birey tarafından dini sınırlara takılmadan tüketilecektir. Ayrıca devlet ve toplumun yerinde sömürüsü söz konusu olduğunda, mikro milliyetçi ve din temelli itirazlardan türetilen yapay terör tehditleri, küresel sermaye temsilcilerine kendilerini bertaraf etmek için meşru birer işgal gerekçesi oluşturacaklardır. 
Günümüzdeki eğilim, bireysel ve kolektif kimliklerin ötesine geçen bir kurguda üçüncü bir aidiyet olarak ulus-üstü/ötesi kimlikler yaratma/oluşturma çabasıdır. Küreselleşme ile birlikte ulusal ve dini kolektif kimlikler erozyona uğramış, bunun yerine dini ve etnik alt-kimlikler ya da çok kültürlülük/çok kültürcülük gibi farklı kavramlar öne çıkmaya başlamıştır. Küresel gelişmeler, ulus-devletin fonksiyonları ile birlikte modernleşme projelerinin tekil kültürel hedeflerinin yaşama geçirilmesini de etkilemiş, var olan kültürel kodların aşınma sürecine girmesine neden olmuştur. Küresel gelişmeler sonucu oluşan kültürel homojenleşme ve düzensizlik, etnik ve dinsel ideolojilerin canlanması bu kimlik gereksiniminin, farklı arayışların bir göstergesidir. Bir yandan etnik ve dinsel eğilimler güçlenirken, diğer yandan ulusal bütünlük kaygısı, yeterli uzlaşımın çeşitli nedenlerle sağlanamadı̆̆ı durumlarda toplumsal istikrarı sarsan sonuçları ortaya çıkarmaktadır (Yorulmaz, 2012, s. 63).

Kültürel düzensizlik ve çok kültürlülük gibi kavramların giderek daha fazla tartışılır hale gelmeye başlamasının temel sebeplerinden birisi de mal ve sermaye ile birlikte emeğin de küreselleşmesi, bu sayede bütün ögeleriyle birlikte bir kültürün başka bir kültür içerisinde ete kemiğe bürünerek göze görünür hale gelmeye başlamasıdır. Emeğin küreselleşmesi, bir yandan ucuz işgücü ve bu bağlamda ulus ötesi göçe bağımlı hale gelen, diğer yandan göçmenlerin kültür, kimlik ve üniter yapılarına vereceği zararları önlemek için katı tedbirler alan Batılı ülkelerin kısır döngüsünü göz önüne almayı gerektirir. Göçmenler nihayetinde kadim kolektif aidiyetleri olan insanlardır. Bunu İsviçreli edebiyatçı Max Frisch "Biz işgücü çă̆ırdık, ama insanlar geldi.” sözüyle çok sade ve güzel betimler. Geldikleri ülkelerde endüstri çarklarının birer elemanı olan göçmenler, kendi kültürel gettolarında din, dil, gelenek gibi kolektif kimlik bileşenlerini yaşamaya devam eden bir sosyal grup, göç alan ülkenin tedbirleri ve toplumsal önyargılarıyla toplumun kıyısında yeşeren bir tropikal vahadır. Bu yalıtılmış vaha;

- Aksi yöndeki tüm çabalara rağmen bünyenin geri kalanını kültürel olarak etkileyen bir toplumsal değişimin tetikleyici unsuru,

- Farklı kolektif aidiyetleriyle dini/kültürel plüralist anlayışın koçbaşı,

- Ötekileştirilme seviyesiyle doğru orantılı biçimde ortaya çıkacak radikal ve fundamentalist -dini, milli, ideolojik vb.- akımların ana rahmi,

- Ötekileştirilmiş yapıları ve informel iç ağlarıyla kıyısında bulundukları toplumsal dokuya kıyasla çok daha kuvvetli bir sosyal dayanışma modeli,

- Kendi ülkeleri ve dünyadaki diğer göçmen topluluklarla geliştirdikleri formel ve/veya informel dış ağları sayesinde bulundukları ülkenin hakimiyet alanına sığmayan küresel toplumsal hareketlerin çıkış ya da yayılım noktası,

- Yukarıda sayılan olguların biri, birkaçı ya da tamamını bünyesinde barındıran münbit bir sosyal alan olma özelliğini her zaman ve coğrafyada korumaya devam edecektir.

\section{Küreselleşme ve Din: Kazanırken Kaybetmek}

Küreselleşme ve dini yapılar arasında hem fırsat hem de riski barındıran ve bakış açısına göre değişen bir ilişki söz konusudur. İlk olarak dini arenada varlık gösteren kurumsal dinlerden sırf dini gruplara ve yeni dini hareketlere kadar bütün yapıların küreselleşme sayesinde küçülen dünyada daha fazla ve farklı yollardan kendilerini daha kolay ifade imkânı bulmasıyla dini 
propagandanın daha geniş kitlelere ulaşması imkânı doğmuştur. Kitle iletişiminin imkânlarından faydalanan dini aktörler, artık her zamankinden daha farklı yöntemlerle ve her mecrada müntesip arayışına girmişlerdir. Daha önemli ve öncelikli etkileşim ise küreselleşmenin dini aktörler üzerindeki yıkıcı etkisidir. Din, bu süreçte daha bireysel yaşanmaya mahkûm edilmiştir. Seküler bir imgeler denizinde din, Berger’in deyimiyle bireyin yoruldukça tutunma ihtiyacı duyduğu küçük adacıklar görevini ifa etmektedir. Sosyal inşa, bütünleşme ve koruma görevlerinden feragat etmek durumunda kalan din, kolektif kimlikleme yetkinliğini en azından geniş kitleler için hızla kaybetmektedir. Modern toplumda kurumsal din, sosyal bütünleşme fonksiyonundan önemli ölçüde kan kaybetmiş, adeta marjinalleşmiştir. Bunun yerine sosyal bütünleşmeyi sağlamak üzere, müntesiplerinin taleplerini göz önüne alarak söylem geliştiren ve örgütlenen sırf dini gruplar güç kazanmışlardır. Tıpkı aile kurumu gibi din de modern zamanlarda başta sosyal işlevleri olmak üzere işlevlerinin önemli bir kısmını kaybetmiştir. Bununla birlikte kurumsal din, endüstri sonrası toplumda hayatta kalabilmek için kendisini ötekilerden öne çlkaracak müntesip endeksli bir çizgi geliştirmek, deyim yerindeyse pazarlamak durumundadır. Zira arayış içerisinde olduğu müntesip tipolojisi, tabiri caizse tamamen gömlek değiştirmiştir. Postmodern müntesip, modernite ve endüstriyel dönüşüm sayesinde mekanik ilişkilerini büyük oranda geride bırakarak organik ilişkilerle yoluna devam eden babasının mirasını kabul etmemektedir. Organik ve endüstriyel babalar, kendine dönük, hedonist, benmerkezci, ama aynı zamanda sığınacak liman arayışındaki çocuklar hediye etmişlerdir insanlığa. Uzaya firlatılan bir mekik metaforunda istikametini kestiremediğimiz insanlık, endüstri devrimiyle ilk yakıt kapsülünü, postmodern dönüşümle ikincisini uzay boşluğuna bırakmıştır. İnsanlık, kendisinden artakalan sonuncusu da dahil olmak üzere bütün mekiğin yakıt kapsüllerinden ibaret olduğunu, bu sonuncuyu firlattıktan sonraki boşluk ve derin sessizlikten anlayacaktır belki de.

Bu süreçte dindarlar muhafazakâr ve liberal olmak üzere iki farklı tercihe yönelmek durumunda kalmıştır. Muhafazakâr tercih, kötülük ve şeytanın yer aldığı geleneksel dini yapıyı ifade eder. Küresel sistemde dini gelenek tarafından tanımlandığı şekliyle dünyaya bağlı kalmayı sürdürme eğiliminde olan muhafazakâr tercih, teorik ve sosyo-psikolojik problemleriyle eskisinden daha dar bir alana çekilmiştir. Liberal tercih ise belirsiz bir şeytan ve kötülük imgesinin kabulüne ve çoğulculuğa vurgu yapar. Liberal dindarlık, dini tasavvurun küresel ortama göre yeniden yorumlanmasını savunur. Bu bağlamda dini çoğulculuk ve liberal teoloji, küreselleşen dünyada daha fazla ön plana çıkma potansiyeline sahiptir (Coştu, 2003, s. 73). Küreselleşme sürecine dayalı olarak kahir ekseriyeti, kendisini yakın dönem hatıralarının aksine marjinalleşmiş halde bulan dindarlar, zamanla global efendilerine meşruiyet sağlayan gözü bağlı otobotlara dönüşür. $\mathrm{Bu}$ durum diğer kurumsal dinler bir tarafa, kurumsal Hiristiyanlık ve küresel sermayenin işbirliğiyle sürekli savunmada kalan İslam toplumları için daha fazla geçerlidir. Sovyetlerin dağılmasıyla birlikte varlık gerekçesi ötekini kaybettiğinden yeni öteki olarak İslam toplumlarını işaretleyen ABD özelinde Batının patolojik tanımlama gayretleri, söz konusu toplumlarda marjinal dindarlık algılarını körüklemekte, Ortodoks İslam çizgisinden ayrışan kimlik savaşçısı sırf dini yapılar, ürettikleri terörle küresel aktörlerin hegemonyasını pekiştirmektedir. Bu kısır döngünün içinden çıkmak için kenara çekilip dışarıdan bakmayı beceremeyen dini söyleme sahip terör örgütleri ve potansiyel hedef kitleleri, varlıklarıyla dünya Müslümanlığına paradoksal bir şekilde sömürü, sefalet ve geri kalmışlı̆̆ı dayatmakta, kader 
haline gelmesine yardımcı olmaktadırlar. Zira ABD küresel, ekonomik ve kültürel yayılmacılığının, sıralamada $\mathrm{ABD}$ merkezli küresel sermaye ve Hollywood gibi asli aktörlerinden sonra gelen ordusunun, dünya barış ve huzurunun tesisi, terörle mücadele gibi sınır ötesi adalet pazarlama gayretlerinin yoğunlaştığı yerler, söz konusu yapay terör örgütlerinin varlık gösterdiği coğrafya ile birebir örtüşmektedir. ABD’nin barış ve huzura ihtiyaç duyduğunu düşündüğ̈ü yerler, bu ihtiyacın hâsıl olmasından sonra bahse konu terör örgütleri tarafından terörize edilmekte, peşi sıra $\mathrm{ABD}$ tarafindan ve ordusu marifetiyle mezkûr bölgeye/ülkeye barış ve huzur ihraç edilmektedir.

Küreselleşme ile birlikte ortaya çıkan yeni dini hareketler ve fundamentalist eğilimler hangi sosyo-psikolojik süreçlerden beslenmektedir, sorusuna cevap aramak anlamlıdır. Kuşkusuz ister yeniden geleneğe dönüş şeklinde, ister geleneği reddederek radikal bir söylemle ortaya çıkmış olsun, her yeni dini hareketin teşekkülünde en azından dört temel sosyo-psikolojik faktörün etkin bir şekilde kendisini hissettirdiği söylenebilir:

1. Küreselleşme sürecinde bazı dini grupların kimliklerini, dolayısıyla varlıklarını kaybetme endişesi içerinde olmaları,

2. Küreselleşmeden kaynaklanan hoşnutsuzlukların kümülatif olarak birikmesi,

3. Üretimin ve verimliğin esas alındığı, maddi rahatlığın asıl hedef olarak ön plana çıkarıldığı tüketim toplumlarında yaşanan engellenmeler ve hayal kırıklıkları,

4. Asr-1 saadet, Tanrının krallı̆̆ı ya da altın çağ gibi her dinde farklı kavramlarla ifade edilen nostaljik mefkurelerle geçmişe özlem duyulması ve böylece ideolojik anlamda yaşanılabilir bir dünyanın yeniden kurulması arzusu (Yapıcı-Yıldırım, 2003, s. 134).

Küresel anlamda Hıristiyanlık ve İslamiyet yaygınlaşırken, Batı Avrupa, Kuzey Amerika ve Japonya'da ise yeni mezheplerin ve grupların ortaya çıkmasıyla bir dini çeşitlilik yaşanmıştır. Bu bir anlamda endüstrileşmiş toplumlara özgü bir gelişme olarak yorumlanabilir. Tabii ki bu çeşitliliğin artışında komünikasyonun ve bilgi akışının önemli katkısı olmuştur. Dini çeşitliliğin diğer bir sebebi ise, özellikle Protestanlığın yoğun bir şekilde artı̧ gösterdiği Güney ve Orta Amerika'da geniş medya ağı ve misyonerliğin yaygınlaşmasıdır (Dark, 2002, s. 68'den akt. Şahin, 2007, s. 82)

Takip edilen dış politikaya dini referanslarla meşruiyet kazandırılması, geçmişte olduğu gibi günümüzde de başvurulan bir yöntemdir. Papa, İslam dünyasına karşı Haçlı Seferleri’ni başlatırken dini referans olarak almıştır. Hıristiyanlarca kutsal kabul edilen yerlerin Müslümanlardan alınmasının, Tanrı'nın isteği ve her Hıristiyan'ın görevi olduğunu belirtmiştir. Osmanlı Devleti de, fetih politikasını dini temellere dayandırmış, fetihlerin "ilay-1 kelimetullah" adına yapıldığını ileri sürerek dini meşruiyet sağlama gereği duymuştur. Özelikle İran, $A B D$ ve İsrail'in dış politikalarındaki dini referanslar, daha yakın örnekler olarak karşımıza çıkar. ABD başkanı Ronald Reagan Sovyetler Birliği’ni "kötülük imparatorluğu" (the evil empire), George W. Bush da Kuzey Kore, İran ve Irak'1 "şer ekseni" (axis of evil) olarak tanımlamıştır. Aynı zamanda İran, ABD’yi "büyük şeytan”, İsrail'i de "küçük şeytan" olarak tanımlamıştır. Irak Devlet Başkanı Saddam Hüseyin, 1'inci Körfez Savaşı sırasında koalisyon güçlerine karşı dini ön plana çıkarmış, Irak bayrağına "Allahu Ekber" ibaresini ekleterek hem kendi halkının hem de İslam dünyasının desteğini kazanmayı amaçlamıştır (Şahin, 2007, s. 8889). 
Küreselleşmenin, biri lokal ve modern öncesi ekonomilerin yerine geçen ve dünya ölçeğinde yaygınlaşan kapitalist sistem, diğeri kitle iletişim teknolojilerindeki gelişmeler olmak üzere iki temel oluşturucu unsuru, aynı zamanda dini hayattaki canlanmalar ve yeni dini hareketlerin doğmasında da etkilidir. Dünyadaki tüm ekonomilerin küresel kapitalizmin etki alanına girmesi, ekonomik küreselleşme olarak tanımlanmıştır. Neo-liberal ekonomik modelin dünya ölçeğinde yaygınlaşması ve dünyanın sosyo-kültürel bakımdan aynılaşması anlamında dünyayı iyice daraltan kitle iletişim teknolojilerinin kültürel küreselleşmeye yol açtığını söyleyebiliriz. Ancak ilki daha çok küreselleşmenin kültürel homojenleştirici yönünü ortaya çıkarırken, ikincisi heterojenleştirici boyutuyla öne çıkmaktadır. Kitle iletişim teknolojilerinin yoğun kullanımı ve sanayileşmiş ülkelere doğru yaşanan iş göçü dini çoğulculuğa neden olmuştur. Bir yandan ekonomik liberalleşmenin dini alanda meydana getirdiği gelişmeler, diğer yandan dini inanç, pratik ve sembollerin serbestçe dolaşımı, dinin daha özgürlükçü yorum ve algılarına yol açmıştır (Bodur, 2012, s. 214-215). Çapcioğlu, küreselleşmenin bir sonucu olan tüketim kültürünün, gündelik hayatın büyük bölümünde olduğu gibi dini hayatta da pek çok unsuru gündelik tüketimin bir parçası haline getirdiğini söyler. Ancak dini unsurların tüketimi ifadesiyle kastedilen, söz konusu unsurların tamamen ortadan kalkması değil tüketim kültürü ile birlikte değer kaybına uğramasıdır. Küresel kültürün taşıyıcıları ile karşılaşan birey veya toplumlar, öncelikle kendi kimliğinin belirleyici unsuru olan dine başvurur. Böyle bir durumda din, toplumu ahlaken yeniden şekillendirmek için köktenci ideolojileri tetikleyebileceği gibi kitle iletişim argümanlarından faydalanarak otantikliğini kaybederken küresel maksatların meşrulaştırma aracına da dönüşebilir (2017, s. 153-154). Giddens’a göre küreselleşme, yerel düzeyde olan bitenin kilometrelerce uzaklıkta meydana gelen olaylar tarafindan biçimlendirilmesinde görüldüğü gibi, uzak bölgeleri birbirine bağlayan dünya çapındaki toplumsal ilişkilerin yoğunlaşmasıdır (1994, s. 62).

\section{Milli Kimlikler ve Küreselleşme: İki Ateş Arasındaki Bayraklar}

Kendisini -teritoryal kırmızı çizgilerle tanımlamak suretiyle egemenlik ve otorite alanını net olarak belirleyen- ulus-devletin karşısına konumlandıran küreselleşme, bütün toplum ve kültürleri istendik bir zeminde birleştirerek aynılaştırma çabalarını devam ettirirken diğer yandan farklılıkları öne çıkaran mikro milliyetçi akımları körükleyerek ulus-devletin ne kadar dirense de paranteze aldığı heterojen kültürel/toplumsal yapısını çözmeye çalışmaktadır. Postmodern dünya ve küresel dokunuşların hâkimiyet alanını daralttığı birleştirici/tekçi yapısıyla ulus-devlet ve dinlerden geriye kalan boşluğu, mikro mensubiyetlerle varlıkları zaten devam eden etnik ve dini gruplar doldurmaya çalışmaktadır. Çatlayan kolektif kimlik algılarıyla düzensiz tavırlar sergileyen böylesi topluluklar adına kimlik siyasetini canlı tutmak isteyen çevreler, hedef kitlelerini kimlik savaşçıları haline getirmeye çalışırlar. Uğruna mücadele edilen kimlik algıları, hızla güçlenerek sosyal grup dinamiklerini belirginleştirir. Mevcut, ya da hedef kitleye mevcut olduğu düşündürülen sanal baskıya karşı, sürekli yapılan vurgularla toplumsal farklılıkların altı çizilerek kolektif direniş biçimleri inşa edilir ve yeni, ayrıksı kültürel alanın savunma duvarları sağlamlaştırılır. Bauman, postmodern yaşamın belirsizlikleri ile baş edebilme kaygısının kimlik uzmanlarına talep yarattığını belirtir. Postmodern belirsizliğe kapılan insanlar, insanın zayıflığı ve yetersizliği üzerine vaaz verecek vaizler yerine, 
"yapabilirsiniz" diyecek ve nasıl yapılacağını gösterecek kılavuzlara ihtiyaç duymaktadır (2000, s. 254-255).

Yerleşik ulus devletlere yönelik küresel meydan okumalar, kimliğin yabancıya karşı milliyet temelinde yeniden yapılanmasını kısmen güçlendirirken, toplumsal yapılar bundan daha hızlı bir şekilde kitlelere dönüştürülerek duyarsızlaştırılmaktadır. Küresel organizatörlerin dünyaya bulaştırdığı değerler, ötekinin sınırlarını keskinleştirdiği için saldırgan tavrıyla tanımlanan milliyetçiliğin karşısında, çok daha saldırgan ve sınır tanımaz bir iştahla konumlanmıştır. Milliyetçilik süreğen bir şekilde sınırlarını, kültürünü, değerlerini ve vatandaşını korumaya çalışarak savunmacı durumda kalmıştır. Aynı zamanda toplumsalın yerini bireyselin aldığı milenyumda, bireyin kendi kimliğini ifade etmeye ve başkaları tarafından tanınmaya duyduğu ihtiyaç arttığından, eşgüdümlü olarak küresel bakış açıssyla bireyseli oluşturma ve yönetme çabaları da kitle iletişimi sayesinde hız kazanmıştır.

Köklerini etnik bir zamandan ve kök yerinden alan şimdiye kadarki kültür emperyalizminden farklı olarak bu yeni küresel kültür, evrensel ve zamansızdır. Eklektik olmakla zamana ve yere karşı kayıtsızdır. Akışkandır ve kalıptan yoksundur. Bugün her yerden daha fazla Batı'da gelişme göstermiş olmakla birlikte, kitle iletişim araçları ve telekomünikasyon sistemleri eliyle postmodern bir kozmopolitan kültür dünyanın her köşesine taşınmaktadır. Burada, şimdide ve her yerdedir. Tarihi ya da tarihleri olmamakla övünür; kullandığı folklorik motifler şimdi ve gelecek yönelimli, bilimsel ve teknik bir kültürün yüzey dekorasyonu için kuyudan çekilip çıartılmıştır (Smith, 2010, s. 243).

Karşılıklı ekonomik bağımlılık, teknolojik ilerleme ve anında iletişim üçlüsü, belki de dünyayı, bolluğun paylaşılacağı daha iyi bir düzene götürebilir. Ama daha bu kapı açlır açılmaz, dünyanın çoğu yerinde bir takım kültürel sorunlar, patlak vermiştir. Ekonomik mantık ve kültürel "mantıksızlık" öngörülerinde karşılıklı olarak derin bir paradoksu barındırmaktadır. İlki bize gelecek yüzyılın dünya ulusal ekonomileri arasında küresel entegrasyon çağı olacağını gösterirken, ikincisi, yüzyılın aynı zamanda etnik talepler ve dirilen milliyetçiliklerin de yüzyılı olacağını gösterir (Fuentes, 1999, s. 123). Küresel güçler, ulusal egemenlik kavramını aşındırır, ticaretten iletişime kadar pek çok faaliyeti etkilerken, aynı zamanda ayrıştırıcı araçları artırmışlar, farklı görüşte olma hakkı ne yazık ki farklı olma savaşına dönüşmüştür (Mandela, 1999, s. 305).

Ulus-devlet yapısına karşı kendisini kaçınılmaz olarak dayatan küreselleşme, ulus-üstü, uluslararası ve çok uluslu yapılanmaları devlet mekanizmasının alacağı kararların tamamında etkin duruma getirmiştir. Artık milli sinırlar daha fazla tehdit altında ve kültürler daha klonlanmıştır. Milli kimlikler, hem kendilerini kapsayan küresel kitle kimliğinin -daha doğru bir ifadeyle kimliksizliğinin- hem de alt grupları olarak kapsadığı daha küçük, otokton, yerel kimliklerin aşındırıcı saldırılarına maruz kalmaktadır. Bahse konu aşınma bireysel kimliklerin yeterince güçlü olmadığı, güç dengesinin daha çok kolektif kimlikler yararına bozulduğu toplumlarda geçerlidir.

Milli devletlerin etki alanlarını daraltarak argümanlarını ellerinden almayı, varlıklarını sorgulanır hale getirmeyi ve sembolikleştirmeyi dayatan küreselleş-tir-me, diğer yandan hâlihazırda devletlerin hukuk sistemleriyle tanımlanmış haklara sahip olan özgür 
vatandaşlarını, yüzleri birbirinin aynısı olan savunmasız tüketici kitleler haline dönüştürerek postmodern köleler yaratmayı hedeflemektedir.

Küreselleşme ve yerellik arasındaki ilişkinin Robertson tarafından kavramlaştırıldığı şeklinde, yerel kültür, milli kültür ve toplumsal kültür gibi, küresel kültürden de söz etmek mümkündür. Küresel kültürün bir boyutu küresel ölçekte değer ve davranış kalıplarının yaygınlaşmasını, bir başka boyutu ise milli ve yerel kültürlerin küresel ölçekte üretilerek canlandırılmasını ifade eder. Bu anlamda küresel kültür hem milletler arasındaki ilişkilerin, hem de bizatihi küreselleşme sürecinin kendi işleyişinin ürünü olarak ortaya çıkar. Küreselleşme ve yerelleşme terimlerinin kısaltılmasından elde edilen ve nihai anlamda aralarındaki gerilime işaret eden bu süreç küyerelleşme ya da glokalleşme olarak isimlendirilir (Akca, 2012, s. 138-139).

Küreselleşme süreci, bu tanıma göre, küresel olan ile yerel olanın iç içe geçmelerinin bir sonucudur. Küreselleşme bu çerçevede dünyanın bir bütün olarak sıkışması ve yerellikleri birbirine bağlamasıyla gerçekleşmektedir. $\mathrm{Bu}$ aynı zamanda içinde yerelliğin keşfini taşımaktadır. Yerelliği keşfetme küresel süreçler aracıllı̆ıyla gerçekleşmektedir. Kültürün küreselleşmesi, bu görüşe bakılırsa, birinci dünyadan üçüncü dünyaya doğru tek yönlü bir akış değildir. Elektronik iletişim, küresel imge ve kimliklerin giderek daha çok paylaşılmasına, birbirine yaklaşmasına ve melezlenmesine yol açmaktadır. Küreselleşme, yalın ve mekanik bir homojenleştirme eşliğinde örgütlenmekle kalmamakta, çeşitli yerelliklerden beslenerek onları evrensel olanlara taşımaktadır. Bu yerel formlarla küresel işleyişin birleştirilmesi sonucunda glokalizasyon (küyerelleşme) adı verilen süreç ortaya çıkmaktadır (Kılavuz, 2002, s. 195). Dünya toplumları bir yandan modernleşmenin nimetlerinden daha fazla faydalanmak, diğer yandan kültürel-otokton değerlerine daha fazla sahip çıkmak istemektedirler. Bu yaklaşım, yüzyıl önce ortaya atılan, TI-YONG (temel prensipler için Çince, pratik yararları için Batı dilleri) veya VOKEN-YOSEI (Japon ruhu, Batı tekniği) (Huntington, 2005b, s. 114) tabirlerinde de kendisini gösterir. Ancak manipüle edilme ihtimali de yayılım hızıyla birlikte ivmelenen bir kitle iletişimi söz konusuyken, küresel mecralarda görünürlügünün arttığını ve kültürlerarası hoşgörüyü artırdığını düşündüğümüz yerellikler, alkol eşliğinde bir akşam sefasına benzer etkiye sahiptir. Kısa süren akşamın sonuna kadar küreselleşmenin etkisine maruz kalarak yerel kültürlerinin yeniden üretilmek suretiyle küresel ölçekte ortaya çıktığı hüsn-ü zannına kapılan milli kimlikler, nimet olarak addettiklerinin ağır külfetler olduğunu hesap pusulası gelinceye kadar anlamayacaklar, ertesi sabah çekilecek baş ağrısı ise yanlarına kar kalacaktır. Çünkü yerelliklerin artan görünürlüğü, acı meyvelerin üzerine dökülen çikolata sosu anolojisinde olduğu gibi sadece kısa bir süre için rahatlama sağlarken, coca-colonizasyona tabi tutulan toplumlar hızlıca yerelliklerinden uzaklaşmakta ve küreselleş-tiril-mektedir. Benzer bir tehdit, dini kimlikler için daha büyük tehlike arz etmekte, yeryüzündeki diğer inançların varlığından her geçen gün daha fazla haberdar olan müntesipler sayesinde din daireleri oldukça geçişken sınırlara sahip olmaya başlamaktadır.

\section{Medeniyetler Çatışması: Tez, Antitez, Sentez ve Yine Tez}

Samuel P. Huntington, 1993 yılında Foreign Affairs Dergisi’nde, öncülü Toynbee'nin yarım yüzyıl önce savunduğu çatışma tezinden (2005) hareketle kaleme aldığı çok tartışılan makalesiyle kınından sıyrılan kılıçları görünür hale getirmiştir. Huntington, bu makalesinde 
21'inci yüzyılın medeniyetlerin çatışmalarına sahne olacağı savını öne sürmüş ve gerekçelendirmiştir. O’nun faraziyesi, bu yeni Dünya' da mücadelenin esas kaynağının öncelikle ideolojik ya da ekonomik olmayacağıdır. Beşeriyet arasındaki büyük bölünmeler ve hâkim mücadele kaynağı kültürel olacaktır. Milli devletler, Dünya'daki hadiselerin yine en güçlü aktörleri olacak, fakat global politikanın asıl mücadeleleri, farklı medeniyetlere mensup grup ve milletler arasında meydana gelecektir. Medeniyet kimliği, gelecekte artan bir şekilde ehemmiyet kazanacak ve dünya büyük ölçüde, Batı, Konfüçyüs, Japon, İslam, Hint, Slav-Ortodoks, Latin Amerika ve muhtemelen Afrika medeniyetleri olmak üzere belli başlı yedi veya sekiz medeniyet arasındaki etkileşimle şekillenecektir (2005, s. 22-25). O, tezini altı temel sebebe dayandırır. İlk olarak, medeniyetler arasındaki tarih, dil, kültür, gelenek ve din farklılıkları gerçek ve esaslıdır. İkincisi, dünya küçüldükçe medeniyet farklılıkları daha güçlü hissedilmektedir. Üçüncüsü, milli kimlikleri zayıflatan sosyal değişim ve ekonomik modernleşme süreçlerinin yarattığı boşluğu dini fundamentalizm doldurmaktadır. Dördüncüsü, gücünün zirvesindeki Batı, Batılı olmayan yollardan dünyayı biçimlendirmek için gittikçe daha fazla arzu, istek ve kaynağa sahip olan Batı dışı ülkelerle yüz yüze gelmektedir. Beşincisi, siyasi ve ekonomik olanlara nisbetle daha az değişme istidadı gösteren kültürel hususiyet ve farklılıkların uyuşma ve ayrışmaları da bu yüzden daha kolaydır. Son olarak, ekonomik bölgecilik artmaktadır (2005, s. 25-27). O’na göre, özellikle İslam, kanlı hudutlara sahiptir ve eğer olursa bundan sonra çıkacak bir dünya savaşı, medeniyetlerin çatıştı̆̆ bir savaş olacaktır (2005, s. 34-38). Tezine yapılan itirazlara "daha iyi bir fikri olan var mı?” sorusuyla cevap verdiği kısa zaman aralığıla yazılmış diğer bir makalesinde, insanların kendilerini tanımladıkları ve uğrunda savaşıp öldükleri şeylerin iman, aile, gen ve inanç olduğunu belirtir. Bunun içindir ki medeniyetler çatışması, global siyasetin merkezi olgusu olarak Soğuk Savaş'ın yerini almakta ve medeniyet paradigması dünyada meydana gelen değişikliklerin anlaşılması ve bunlarla baş edilmesi için, diğer herhangi bir alternatiften daha iyi, faydalı bir başlangıç noktası temin etmektedir (2005a, s. 83-84).

Huntington'un tezi, yayınlanmasının hemen akabinde dünya çapında aksi sedasını bulmuştur. Örneğin Ajami, denemede Batı'nın yeterince incelenmediğini, pürüzden ve çatlaktan azade bir görünümde ve kendi kale duvarları içinde düzenli bir biçimde sunulduğunu belirtir (2005). Nitekim başka bir makalesinde Huntington, Batı ve Batı kültürü deyince Grek felsefesi ve rasyonalizmi, Roma Hukuku, Latince, Batı Hıristiyanlığı, Avrupa dilleri, dini ve dünyevi otoritenin ayrılması, kanun hâkimiyeti, sosyal çoğulculuk ve sivil toplum, temsil kurumları, ferdiyetçilik gibi özelliklerin anlaşılması gerektiğini söyler (2005b, s. 110-113). O’nun tezindeki satır aralarında okunabilen genel kaygı, ABD’nin büyük ağabeyliğini yaptığı Batı toplumunun birlik ve bütünlüğüdür. Bartley, Amerikan kültürünün dünyanın her yerine ulaştı̆̆ı ve yeni Japon payitahtı prensinin Harvard'ta eğitim gördüğü bir küresel entegrasyon mevcutken, şüphelerin yersiz olduğu ve Batı'nın kendisine güvenmesi gerektiğini belirtir (2005, s. 62). Mahbubani, Batı'nın çifte standart oluşturan uygulamalarının, Doğu'daki algısına negatif yönde ivme kazandırdığı ve olası bir çatışmaya bunun sebep olacağını belirtir (2005, s. 66-71). Fukuyama'ya göre Ortadoğu dışında, medeniyetlerin kimliği, milli devlet kimliğine nazaran çok daha zayıf hissedilmektedir. Bugün Avrupa'da yaşayanların çoğu, kendisini Hıristiyanlık medeniyetinin bir üyesi olarak değil, öncelikle bir Alman, bir İtalyan ya da bir İrlandalı, hatta büyük ihtimalle Avrupalı olarak görmektedir. Dünyanın diğer bölgelerinde de durum daha farklı değildir. Mesela Çin, Kore, Vietnam ve Singapur Konfüçyen toplumlar olmalarına 
rağmen, bunların her biri farklı tercihler ve buna bağlı olarak da farklı ittifaklar içindedir. Böyle olduğu için de, bu ülkeler diğer ülkelerle ve birbirleriyle olan ilişkilerinde hiçbir zaman homojen bir yapı olarak davranmamaktadır. Kültür etkileşimi Huntington'un yorumlarının aksine, kriz ve çatışmaya değil intibak, hoşgörü ve yenilenmeye yol açmaktadır (2005, s. 196-198). Patlayan ve çöken olarak ikiye ayırdığı dünya tanımıyla Ahmed, patlayan Batının, medya üzerindeki egemenliği aracilığıla kültürel sınırlarını dünyanın bir ucundan diğer ucuna genişletmeyi sürdürürken, geleneksel uygarlıkların buna bazı alanlarda direneceği, bazı alanlarda uzlaşacak ve değişeceklerini iddia eder. O’na göre materyalizmi reddiyesiyle sufi mesaj, sulh-i kul'la (herkesle barış içinde olmak) olumlu bir barış ve kardeşlik çağrısına sahip olarak Batı uygarlığının egemen değerlerine karşı bir denge sağlar. Bu çağrı renk ve ırk ayrımından muaftır ve zamanın etkisine karşı koyabildiği için özellikle Avrupa'da din değiştirenler arasında hatırı sayılır bir etki kazanmıştır. Kaldı ki postmodern çağda araya keskin sınırlar çekerek bunları korumak artık kolay değildir (2005:227-243). Fransız düşünürler Mongin (2005, s. 290-307) ve Beaudet (2005, s. 308-317), birbirlerini çağrıştıracak şekilde en ilkel kültürlerin bile diğer kültürlerle etkileşim olmadan oluşmasının imkânsızlığı ispatlanmışken, Huntington’un saflaştırdığı ve katıksızlaştırarak çatışacaklarını öngördüğü medeniyetler tezinin kurmaca olduğu ve emperyalizme hizmet ettiğini belirtirler. Sullivan, sadece tezin kavramsal açıdan çürük, olgusal bakımdan yanlış olduğunu belirtmekle kalmaz, aynı zamanda faydasız olarak nitelendirdiği tezin yeni bir kutuplaşmaya kesin katkısı olacağından endişe ettiğini belirtir (2005, s. 338).

Amin, kapitalizmin daima krizlerini, hatalarını ve suçlarını temize çıaran makul açılamaları sağlayan akademisyenleri ve siyaset bilimi yazarlarını ödüllendirmeye hazır olduğunu belirtirken, Huntington’un akademik yetkinliğini kimlerin hizmetine verdiğini adeta haykırır. O’na göre kültürler ve dinler sürekli olarak değişmekte ve değiş̧im açıklanabilmektedir. Sistematik bir kültürler çatışması yoktur. Tamamen başka şeylerden kaynaklanan çatışmaların çok daha derin nedenleri vardır. Bu çatışmaların ancak bir kısmı kültürel boyuta sahiptir. Bir kitle mücadelesinin stratejisini belirlemek için, işe içinden geçtiğimiz tarihsel dönemde kapitalizmin çelişmelerini analiz ederek başlamak gerekmektedir (2005, s. 350-358).

Medeniyetleri çatışıran söz konusu tez üzerine Türkiye'den Ahmet İnsel (2005; 2005a; 2005b), Doğu Perinçek (2005, s. 394-396), Ömer Laçiner (2005, s. 444-463), Yasin Aktay (2005, s. 464473) ve diğer birçok isim fikir serdetmişse de, Binnaz Toprak (2005, s. 388-390), Muzaffer Özdağ (Şenel, 2005, s. 409-420) ve Ahmet Davudoğlu (2005, s. 369-375), düşüncelerini Samir Amin kadar doğrudan ifade eden düşünürler olarak öne çıkmışlardır. Davudoğlu, Huntington'ın medeniyet çatışmaları incelemesinde, çatı̧̧ma alanları vurgulanırken, kaynaşma, müsamaha ve sentez alanlarının yok farz edildiğini belirtir. O'na göre Huntington’a ait bu yaklaşımın metodolojik bir hata sonucu değil, önceden belirlenmiş teorik bir tercih sonucu olduğunu ortaya koyan ciddi ipuçları vardır. Bu teorik tercih makalenin misyonu ile yakından ilgilidir. Huntington bu tahlil ile Batı medeniyetinin felsefi entelektüel birikimini, sosyal kültür ve uluslararası sistem üzerindeki belirleyici vasfını göz ardı etmektedir. Dolayısıyla da bunalımın vebalini ve ortaya çıkan çatı̧̧ma alanlarının yükünü, tekelci Batı medeniyeti tarafından hayat alanları gittikçe sınırlandırılmış yerel medeniyetlere ve otantik kültürlere yüklemektedir. Böylece gelecekteki bunalımın suçluları şimdiden ilan edilmiştir. Bu noktada 
Huntington, Fukuyama'nın yarım bıraktığ demokratik sistemle insanoğlunun nihai hedefini gerçekleştiren Batı medeniyeti (Fukuyama) ve detaydaki bunalımların çıkmasına sebep olan yerel kültür ve medeniyet çatışmaları (Huntington). Fukuyama'nın tezi ile Batı medeniyetinin felsefi ve sistemik unsurları yüceltilirken, Huntington'ın tezi ile başta İslam ve onu takiben Konfüçyanizm olmak üzere diğer bütün kültür ve medeniyetler, çıkan siyasi huzursuzluk ve bunalımların kaynağı ve sorumlusu olarak takdim edilmektedir (2005, s. 371,372).

Her ne kadar Huntington tarafından bilimsel olarak gerekçelendirilmeye ve mantık dairesi içerisinde açıklanmaya çalışılsa da medeniyetler çatışması, manidar zamanlaması dikkate alındığında, iki kutuplu dünyada zıddını kaybeden tarafın, emperyal gelecek kaygısıyla var olmak için düşman yaratmaya ve medeniyetleri çatıştırmaya çalışma gayretinin sosyo-bilimsel dile dökülmüş itirafı görünümündedir. Tek taraflı aktarımlarla küreselleştirilen 3’üncü Dünya ülkeleri, farkında ve rahatsız olmalarına rağmen karşı koymakta güçlük çektikleri bir değişimi yaşamaktadır. Bununla birlikte modern köleliğe zorlandıklarının farkında oldukları ve küyerelleşmenin faydalarına iyimser bir çaresizlikle iman ettikleri halde kültürel aktarımı gerçekleştiren sömürgen Batının patolojik tanımlama kalıplarına yüksek bir mahkûmiyet hissi duyarlar. Son olarak küresel aktörler bir yandan coca-colonizasyon tabirinin tam karşıladığ 1 şekilde tekil, tıpkıçekim, yüzsüz bir kültürü dayatırken, diğer yandan ulus altında çokkültürlülük hatta çokkültürcülük kavramlarının hâkimiyeti için janusyen -ikiyüzlü- bir tavırla çatışmaları körüklemektedir. Ancak küreselleşmenin tek taraflı kültürel ve ekonomik aktarımına imkân sağlayan kanallar, aynı zaman ve zemini bulanıklaştırdığı, uzak-yakın, dostdüşman ve iyi-kötü tanımlarını da değiştirdiğinden çatışma her zaman kazanmaya koşullu tarafın lehine sonuçlanmama ihtimalini içerisinde mutlak biçimde barındırmaktadır.

\section{Tranzisyonel Toplum ve Kimlik Savaşçıları}

Başlangıçta kimlik politikalarının, modernite ve küreselleşmenin aşındırdığı din, etnisite ve kadim mekanik ilişkiler gibi toplumsal tutunum noktalarına geri dönüşü temsil ettiği söylenebilse de, bütün bu romantik çabaların, düş kırıklıkları ve toplumsal aldatılmışlık duygusunun ardına saklandığı kâğıttan kaleler olduklarının anlaşılması uzun sürmeyecektir. Kimlik siyasetçisi kılıcını gözlerini kapatarak savurduğu ve hareketini sadece direniş üzerine kurguladı̆̆ 1 için kitlesini yalnızlaştırmak ve marjinal hale getirmekten başka bir şey yapamaz. Bir yandan homojenize ve özdeş olmak için tabanında çatıştığı farklılıkların sayısını artırır ve bireyi diğer tüm kimliklerden arındırırken, diğer yandan iletişim yoksunu hareket giderek kör ve sağır hale geldiğinden, ötekileştirdiği kimlikler hızla varlık gerekçelerini yitirir. Böylece etiketlediği kitle tarafından kimliğin, bir sürecin sonunda inşa edilmiş olduğu göz ardı edilmeye, unutulmaya başlanır. Giderek kutsallaştırılan kimlik, siyasetçisinin atfettiği özelliklerle her türlü zafiyet ve eleştiriden azade hale gelir. Ve sonunda, kitlesine kutsal görünen ulu çınar, fiske vuruşuyla yıkılır birgün...

Post-endüstriyel yapı kırsal topluluklarda kente göçü, göç olgusu söz konusu muhacir kitlelerde ekonomik sıkıntıyı, ekonomik sıkıntı ise yeni kimlik arayışlarını beraberinde getirecek, eşzamanlı olarak çok hızlı bir şekilde etnikleşme ve sırf dini gruplarda (tarikat ve cemaat) müntesipleşme süreci de tetiklenmiş olacaktır. $\mathrm{Bu}$ bağlamda ülkemizde yaşanan etnikleşme/müntesipleşme sürecinin bir ayağı da belirtildiği üzere üretim ve tüketim 
dünyasından dışlanmadır. Çünkü köyden taşı toprağı altın olan kente, feodal kökleri ve kültürüyle birlikte göç etmiş olan geniş aile, kent kültürüyle yüzleştiğinde kültürel bir ergime sürecine girer. Kent yaşamında, özellikle gettoda, sıyrıldığı eski kimliğinden sonra, üretim çarkına dâhil olamadığından farklı bir kimlik edinemeyen ve kent kültürünün dayattığı çekirdek aile yapısıyla birlikte mekanik bağları zayıflayan birey, zaten ortalarda dolaşarak kutsal isyan havasıyla kendisine yeni sahipler arayan, etnik/dini grup kimliğine sarılır. Kentin sokaklarında yeni bir kolektif ifade biçimi, coşturucu bir isyan ruhu ve birey aklının kitlenin gücüne kendisini feda ettiği bir kesin inanç kültü bulduğu için, kitle psikolojisiyle yakarak, yıkarak, korku salarak, dışlandığını düşündüğü yeni ve güçlü kimliği için savaşmak son derece olası bir hal tarzıdır. Bir diğer hal tarzı sosyal şartlar gereği etnikleşmek yerine her iki dünyada kurtuluşa ermek için bir dini gruba bağlanmak şeklinde kendisini gösterir. Onun için kendi hayatı ve mevcut düzen, yıkılıp yeniden kurulması gerekecek kadar köhnedir. Değersiz ve anlamsız benliğine ihtiyaç duyduğu değeri katacak bir bütünün parçası olmaya her haliyle hazırdır. Kentin sokaklarında değersizleşen, silikleşen benliğinin yerine, öz saygısını yeniden kazandırabilecek bir grup kimliğine, bencil çıkarları feda etmenin verdiği gururu bulur. $\mathrm{Bu}$ sayede kitle psikolojisi ve dışlanmış/dışlayan kimliğiyle beraber yıkılan feodal gururunu da tatmin eder. Ezilmiş ve hiçleşmiş bir birey olmaktansa, büyük ve güçlü bir bütünün parçası, ezici gücünü temsil eden bir grubun üyesi olmak çok daha tatmin edicidir. Unutmamak gerekir ki bireyin sahip olduğu kimliklere yüklediği değer, bahse konu kimliğin bireye sağladığı tatmin duygusuyla çok yakından ilgilidir. Ayrılıkçı etnik ya da dini hareketin önünde set olabilecek en büyük güç, aynı zamanda ekonomik sistemin de yegâne -ya da en büyük ve etkili- kontrolörü olan devlet aygıtının yeterli seviyedeki denetim gücüdür. Bir yönetişim mekanizması olarak devletin, her alanda denetim mekanizmasını işletmekten ve hukuk sistemini tüm coğrafyasında eşit ve adil bir biçimde yürütmekten aciz olduğu durumlarda, önüne geçilmek istenen etnik hareketin güçlenerek artması bir yana yenilerine vesile olunması işten bile değildir.

Bu bağlamda, kimlik siyaseti güden çevrelerin güdüledikleri sosyal grupları getirmek istedikleri nokta, direniş kimliğidir. Direniş ve eylemlilik süreci başarıya ulaştıkça, grubun bunu yöneten siyasi elitin yaptıklarına ve mevcut duruma bağlılığı marjinal doyum eşiğini aşmaktan dolayı etkisizleşerek gücünü yitireceğinden, direnişin sürekli başarılı olması, devamı açısından yıpratıcı bir durumdur. Siyasi elit, direniş ve eylemlilik sürecinin kesintiler halinde ulaştığı başarı ya da düzensiz aralıklarla yaşadığı başarısızlığın, oluşturmaya çalıştığı kimliklenme süreci için uzun vadede, sürekli başarıdan daha sağlıklı sonuçlar doğuracağını bilir.

\section{Sonuç}

Küreselleşme, sürekli ve hummalı bir çabayla bütün renkleri aynı palette birleştirerek ortaya tarif edilemeyen ya da herkes tarafından farklı tariflerle açıllanan bir renk çıarmaya çalışmaktadır. Bunun için başta kitle iletişimi olmak üzere mal ve paranın sınır tanımayan hareketli karakterleri oldukça kullanışlı araçlar olarak öne çıkmaktadır. Karşılaştığı en büyük direnç noktaları, eksik yönlerini tamir etmeye çalışarak milli kimliklerini sürekli yeniden inşa eden ulus devletlerdir. Bu durumda milli kimliklerin de aslında sanıldığı kadar homojen

\footnotetext{
${ }^{2}$ Kesin inançlı bireyin zihni yapısı ve kitle hareketlerinin anatomisi konusunda detaylı ve saptayıcı bir çalışma için Bkz. Eric Hoffer, Kesin İnançllar, (Çev. Erkıl Günur), İm Yayınları, İstanbul, 2005.
} 
olmadığını ispat etmek için mikro milliyetçi hareketlerle zayıflatmaya çalışmak küreselleş-tirme aktörleri için asla ihmal edilmeyen bir yöntemdir. Yukarıdan bilindik kanallar ve biteviye küresel aktarımlar marifetiyle aşındırılan milli kimlikler, eşzamanlı olarak aşağıdan da mikro milliyetçi çabalar ve canlandırılan ulus altı etnikleşmeler vasıtasıyla çatlatılarak parçalanmaya çalışılır. Batılı değerlerin aktarımı olarak da tanımlanabilecek olan küreselleşme ve postmodern kültürün en belirgin hedeflerinden bir diğeri de monist/tekçi yapısıyla İslam dinidir. Batılı sağlıksız İslami tanımlamalar, İslam'ı postmodern bir kalıba oturtma ve tıpkı Hıristiyanlık'ta olduğu gibi gökyüzüne, öte dünyaya hapsetme çabalarına karşıllk, sadece bireysel zihni yapıyı değil aynı zamanda dünyevi-sosyal hayatı düzenleme iddiası olan İslam dini, savunmacı pozisyonunda kalmıştır.

Milli kimlik, uzun soluklu, aralıksız ve çift taraflı küresel saldırılar karşısında varlğ̆ını devam ettirmek için öncelikle bileşenlerini sürekli olarak güncellemeli, varlığına yapılan saldırıları içerik ve dayanaktan yoksun bırakacak vizyoner adımları hayata geçirme konusunda eline çabuk ve mahir davranmalıdır. Özellikle içeriden kolektif yapısına zarar verme ihtimali olan mikro milliyetçi akımlar, ulus altı oluşumlar ve güç devşirme çabasındaki kökü dışarıda sırf dini grupları marjinalleştirmek suretiyle hedef kitlelerini daraltarak yok etme çabası devamlılık arz etmelidir. Aynı doğrultuda öz itibariyle aynı ancak zahiren farklı tehditlere maruz kalan İslam dini için de çözüm arayışları benzer istikamete sahip olmak durumundadır. İslam, Batıll, postmodern aktarımların karşısında özüne sadık kalarak söz konusu postmodern dile galebe çalabilecek bir lisan geliştirmek suretiyle mevcut vizyoner potansiyelini görünür kılmalı, kendi alt-kültür bileşeni olarak ortaya çıkan ve içerik kaybı/tahrifine sebebiyet verme ihtimalini barındıran sırf dini grup ve yapılanmalar konusunda postmodern hassasiyetlerle daha dikkatli tavır geliştirmelidir.

Küreselleşme, ulus kimlikleri parçalayarak mikro milliyetçi/etnik/çatışmacı kimlikleri ve kimlik savaşçlarını körükler, yayılmacı dinleri parçalayarak içerinden öncelikle sırf dini gruplar, yeni dini hareketler türemesinin yollarını açar. Coca-colonizasyon, otokton kültürleri renksiz, kokusuz, tatsız, tuzsuz fabrikasyon ve gündelik ürünlere, bireyleri ise mimiksiz, suratsız otobotlara dönüştürür. Bu süreç, kültür endüstrisi ürünlerinin pompalandığı bireylerde önce sıradan seçenekler, sonra ise aynı seçeneklerin dayatıldığı kısırdöngüler oluşturur. Birey, seçme ayrıcalığını yaşadığı renklerin kısa sürede dokusuna zerk edildiğini, baştaki seçeneklerin vazgeçilmesi düşünülemeyen zaruret ve ihtiyaçlar haline geldiğini fark edemeyecek kadar kendinden geçmiştir. Bu arada küresel organizatörler tarafından yapılandırılan ve önüne kattığı her şeyi tozlaştıran bu makinede öğütülmeye direndiği görüntüsünü veren din temelli terör örgütleri, mahalli kültürleri ve dini kolektif kimlikleri konusunda hassasiyet taşıdığı için sürekli marjinalleşen bireyler sayesinde üstlendikleri küresel rollerini oynarlar. Bu rol, ürettikleri terör sayesinde ulusal direnç mekanizmalarının kırılması ve küresel sermayenin sömürgen ordularıyla dünyanın istedikleri her coğrafyasında barışın tesisi için gösterdikleri varlığın meşrulaştırılmasıdır. Aslında birinin diğeriyle bağlantısının olmadığı zannedilen faaliyetlere sahne olan bu süreç, şimdilik hep aynı sonucu doğurmaya devam edecek gibi görünmektedir. 


\section{Kaynakça}

Ahmed, E.S. (2005). Medya Moğolları Bağdat Kapısında. Levent Cinemre (Çev.), Murat Yılmaz (Der.), Medeniyetler Çatışması içinde (s.227-244). Ankara: Vadi.

Ajami, F. (2005). Davet: Fakat Dediler ki Kulak Vermeyeceğiz. Mehmet Öz (Çev.), Murat Yılmaz (Der.), Medeniyetler Çatışması içinde (s.50-59). Ankara: Vadi.

Akca, Ü. (2012). Küreselleşme ve Türk Milliyetçiliği, Dün ve Yarın. Ankara: Altınpost.

Aktay, Y. (2005). Eskatolojilerin Sonu’ndan Çatışmanın Devamına. Murat Yılmaz (Der.), Medeniyetler Çatışması içinde (s.464-473). Ankara: Vadi.

Amin, S. (2005). Emperyalizm ve Kültürelcilik Birbirini Tamamlıyor. Murat Yılmaz (Der.), Medeniyetler Çatışması içinde (s.350-358). Ankara: Vadi.

Bartley, R.L. (2005). Batı Kendisine Güvenmelidir. Erol Göka (Çev.), Murat Yılmaz (Der.), Medeniyetler Çatışması içinde (s.60-65). Ankara: Vadi.

Baudrillard, J. (2018). Simülakrlar ve Simülasyon. Oğuz Adanır (Çev.), Ankara: Doğu Batı.

Bauman, Z. (2000). Postmodernlik ve Hoşnutsuzlukları. İsmail Türkmen (Çev.), İstanbul: Ayrintı.

Beaudet, P. (2005). Atina ve Misır'da, Antik Uygarlıklar ve Batı'nın İcat Edilmesi. Kadir Cangızbay (Çev.), Murat Yılmaz (Der.), Medeniyetler Çatışması içinde (s.308-317). Ankara: Vadi.

Bodur, H.E. (2012). Küreselleşme ve Din. Din Sosyolojisi El Kitabı içinde (s.211-219). Ankara: Grafiker.

Coştu, Y. (2003). Homojenlik ve Heterojenlik Arasında Küreselleşme-Din İlişkisi. İslâmiyât, 6(2), 67-76.

Çapcioğlu, İ. (2017). Küreselleşme Kültür ve Din. Ankara: Otto.

Dark K.R. (2002). Large Scale Religious Change and World Politics. Religion and International Relations. New York, 50-82.

Davudoğlu, A. (2005). Fukuyama'dan Huntington'a: Bir Bunalımı Örtme Çabası ve Siyasi Teorinin Pragmatik Kullanımı. Murat Yılmaz (Der.), Medeniyetler Çatışması içinde (s.369-375). Ankara: Vadi.

Fuentes, C. (1999). Federalist Yol. Belkıs (Çorakçı) Dişbudak (Çev.), Nathan Gardels, Wole Soyinka (Ed.), Yüzyılın Sonu içinde (s.123-128). İstanbul: Türkiye İş Bankası Kültür.

Fukuyama, F. (2005). Savaşların Geleceği. Kadir Koçdemir (Çev.), Murat Yılmaz (Der.), Medeniyetler Çatışması içinde (s.195-208). Ankara: Vadi.

Giddens, A. (1994). Modernliğin Sonuçları. Ersin Kuşdil (Çev.), İstanbul: Ayrıntı.

Huntington, S.P. (2005). Medeniyetler Çatışması mı?. Mustafa Çalık (Çev.), Murat Yılmaz (Der.), Medeniyetler Çatışması içinde (s.22-49). Ankara: Vadi.

Huntington S.P. (2005a). Cevap: Medeniyetler Çatışması Değilse Nedir? Soğuk Savaş Sonrası Dünyasının Paradigmaları. Mehmet Öz (Çev.), Murat Yılmaz (Der.), Medeniyetler Çatışması içinde (s.72-84). Ankara: Vadi. 
Huntington, S.P. (2005b). Batı Tektir, Ama Evrensel Değildir. Fazıl Osman Yıldırım (Çev.), Murat Yılmaz (Der.), Medeniyetler Çatışması içinde (s.108-122). Ankara: Vadi.

Hoffer, E. (2005). Kesin İnançlılar. Erkıl Günnur (Çev.), İstanbul: İm.

İnsel, A. (2005). Yeni Sağ ve Uygarlıklar Savaşı. Murat Yılmaz (Der.), Medeniyetler Çatışması içinde (s.376-377). Ankara: Vadi.

İnsel, A. (2005a). Yeni Sağ ve Uygarlıklar Savaşı II. Murat Yılmaz (Der.), Medeniyetler Çatışması içinde (s.378-379). Ankara: Vadi.

İnsel, A. (2005b). Totalitarizm Umacısı ve Yumuşak Konsensüs. Murat Yılmaz (Der.), Medeniyetler Çatışması içinde (s.380-381). Ankara: Vadi.

Kılavuz, U.M. (2002). Küreselleşen Dünyada Din. Uludă̆ Üniversitesi İlahiyat Fakültesi, 11(2), 191-212.

Laçiner, Ö. (2005). Yeni Bir Çağın Eşiğinde Kültürel Kaynak ve Kimlik Üzerine Bir Çerçeve. Murat Yılmaz (Der.), Medeniyetler Çatışması içinde (s.444-463). Ankara: Vadi.

Mahbubani, K. (2005). İnhitatın Tehlikeleri: Diğerlerinin Batı’ya Öğrettikleri. Mustafa Çalık (Çev.), Murat Yılmaz (Der.), Medeniyetler Çatışması içinde (s.66-71). Ankara: Vadi.

Mandela, N. (1999). .Ulus-Devletin Silinişi. Belkıs (Çorakçı) Dişbudak (Çev.), Nathan Gardels, Wole Soyinka (Ed.), Yüzyılın Sonu içinde (s.303-310). İstanbul: Türkiye İş Bankası Kültür.

Mongin, O. (2005). Jean François Bayart ile Mülakat: İdeoloji Olarak Kültürcülük Üzerine. Ruşen Çakır (Çev.), Murat Yılmaz (Der.), Medeniyetler Çatışması içinde (s.290-307). Ankara: Vadi.

Perinçek, D. (2005). Hıristiyan-Müslüman Çatışması. Murat Yılmaz (Der.), Medeniyetler Çatışması içinde (s.394-396). Ankara: Vadi.

Smith, A.D. (2010). Milli Kimlik. Bahadır Sina Şener (Çev.), İstanbul: İletişim.

Sullivan, A. (2005). Muhafazakârlık, Çoğulculuk ve İslam. Melih Yürüşen (Çev.), Murat Yılmaz (Der.), Medeniyetler Çatışması içinde (s.337-349). Ankara: Vadi.

Şahin, M. (2007). Din-Dış Politika İlişkisi: ABD Örneği. (Yayımlanmamış doktora tezi). Gazi Üniversitesi Sosyal Bilimler Enstitüsü, Ankara.

Şenel, Ş.A. (2005). Medeniyetler Çatışması Üzerine Muzaffer Özdağ İle Mülakat. Murat Yılmaz (Der.), Medeniyetler Çatışması içinde (s.409-420). Ankara: Vadi.

Toprak, B. (2005). Huntington, Batı'nın Önyargılarını Yansıtıyor. Murat Yılmaz (Der.), Medeniyetler Çatışması içinde (s.388-390). Ankara: Vadi.

Toynbee, A. (2005). Medeniyetlerin Karşılaşması. Ufuk (Uyan Çev.), Murat Yılmaz (Der.), Medeniyetler Çatışması içinde (s.359-365). Ankara: Vadi.

Yapıcı, A., Yıldırım M. (2003). Küreselleşme Sürecinin Dini Kimliklere Etkisi:-Sosyal Psikolojik Bir Değerlendirme. Dini Araştırmalar, 6(17), 117-138.

Yorulmaz, M. (2012). Din ve Kimlik İlişkisi Bağlamında Türkiye'de Kimlik Arayışları- Yapısal Bir İçerik Analizi. Elektronik Siyaset Bilimi Araştırmaları, 3(2), 59-74. 